\title{
PERENCANAAN BISNIS BRIKET TEMPURUNG KELAPA BERBASIS WIRAKOPERASI DI KABUPATEN BOGOR
}

\author{
Fitria Na'imatu Sa'diyah' ${ }^{1)}$, dan Lukman M Baga ${ }^{2)}$ \\ ${ }^{1,2)}$ Departemen Agribisnis, Fakultas Ekonomi dan Manajemen, Institut Pertanian Bogor \\ 1)fitirans00@gmail.com
}

\begin{abstract}
Bogor is capable of producing 16208 tons of coconuts a year, and a big amount of coconut shells. This kind of shells can be a very valuable business commodity when processed into briquette. However the majority of Indonesian coconut farmers have only a little number of coconuts trees, so that the shell production is low and the farmers find it difficult to enter the briquette industry. Therefore, the coconut farmers need to join in the business based on cooperative approach to enter briquette industry. The coconut farmers who become members of the cooperative will get the guidance to process coconut shells into charcoal .The charcoal produced by farmers is used as raw material of making briquette. The market target of briquette will be Japan and the product will be sold at Rp11 829 per kilogram. This business gives financial benefit to the cooperative as the NPV is Rp5.1 milliards, gross B/C is 1.18, and payback period is 2 years 8 months. Nonfinancially, this business gives social benefit to the farmers who are members of the cooperative, because the cooperative buys the farmers' charcoal in a good price, i.e. higher than the market price. Besides, those farmers will also get share profit from the cooperative.
\end{abstract}

Keyword(s): briquette, coconut, cooperative entrepreneur, investment

\begin{abstract}
ABSTRAK
Bogor mampu menghasilkan kelapa sebanyak 16208 ton, sehingga akan menghasilkan limbah berupa tempurung kelapa yang banyak. Tempurung kelapa dapat bernilai ekonomi apabila diolah menjadi briket. Akan tetapi karakteristik dari sebagian besar petani kelapa Indonesia hanya memiliki sedikit pohon kelapa, sehingga produksinya rendah dan sulit untuk masuk dalam industri briket secara individu. Oleh karena itu para petani kelapa perlu bergabung dalam usaha berbasis wirakoperasi untuk memasuki industri briket. Para petani kelapa yang menjadi anggota koperasi akan mendapatkan bimbingan dalam mengolah tempurung kelapa menjadi arang. Arang yang dihasilkan petani dijadikan bahan baku pembuatan briket. Target pasar dari produk ini adalah Jepang. Produk ini dijual dengan harga Rp11 829 per kg. Secara finansial bisnis ini memberikan keuntungan jika dilihat dari nilai NPV sebesar Rp5.1 Miliar, gros B/C sebesar 1.18, dan payback period sebesar 2 tahun 8 bulan. Sedangkan secara nonfinansial bisnis ini memberikan manfaat sosial dalam menyejahterakan petani dengan harga arang yang lebih tinggi dari harga pasar serta bagi hasil usaha briket.
\end{abstract}

Kata Kunci: briket, investasi, kelapa, wirakoperasi

PENDAHULUAN

Kelapa merupakan tanaman yang mudah ditemui di Indonesia, baik di daerah pegunungan maupun dataran rendah banyak terdapat pohon kelapa. Lahan yang digunakan sebagai per- 
kebunan kelapa di Indonesia, yaitu sekitar 3787283 Ha dengan pertumbuhan sebesar 0.6 persen yang terjadi pada tahun 2013. Selain peningkatan luas lahan yang digunakan untuk perkebunan kelapa, terjadi pula peningkatan produktivitas kelapa sebesar 1.12 persen yang tejadi di tahun 2013 (BPS 2014). Akan tetapi jika dilihat dari produktivitasnya, kelapa tergolong rendah yaitu sekitar 50 persen dari potensi produksinya. Oleh karena itu produktivitas kelapa masih berpotensi untuk ditingkatkan ${ }^{3}$.

Salah satu daerah yang mempunyai potensi dalam menghasilkan kelapa adalah Kabupaten Bogor. Kabupaten Bogor pada tahun 2012 mampu menghasilkan kelapa sebanyak 16208 ton per tahun (BPS Kab. Bogor 2013). Potensi ini juga diikuti dengan adanya potensi limbah tempurung kelapa yang besar pula.Untuk itu limbah ini perlu dimanfaatkan dengan baik. Tempurung kelapa ini dapat diubah menjadi barang bernilai ekonomi tinggi, apabila dilakukan penambahan nilai yaitu dengan cara mengubahnya menjadi briket tempurung kelapa.

Permintaan akan briket mempunyai kecenderungan yang terus meningkat, terutama di pasar internasional seperti pada Lampiran 1. Walaupun data tersebut tidak hanya terdiri dari ekspor akan briket, namun setidaknya dapat mewakilkannya. Briket yang dimasksudkan dari data juga bukan briket tempurung kelapa tapi briket yang terbuat dari kayu.
Akan tetapi dapat diasumsikan bahwa briket tempurung kelapa dapat mensubtitusi briket kayu sehingga data ini digunakan untuk melakukan pendekatan dalam melihat peluang pasar. Namun untuk sekarang ini, di Indonesia belum banyak perusahaan briket tempurung kelapa, yang dibuktikan dengan belum tercatatnya briket kelapa menjadi variabel tersendiri pada data di Badan Pusat Statistik. Hal ini berarti belum banyak produksi briket tempurung kelapa yang dihasilkan di Indonesia.

Petani kelapa cenderung kurang tertarik dengan bisnis ini karena kurangnya informasi yang diperoleh akan peluang usaha, serta keterbatasan sumberdaya modal usaha yang dimiliki. Selain itu, dalam menjalankan bisnis ini dibutuhkan banyak input tempurung kelapa, sedangkan kuantitas tempurung kelapa yang dimiliki oleh individu petani masih jauh dari persyaratan tersebut. Sehingga untuk dapat memasuki industri briket tempurung kelapa perlu adanya perencanaan bisnis berbasis wirakoperasi.

Bisnis dengan sistem wirakoperasi adalah usaha yang dilakukan secara bergotong-royong dengan dipimpin oleh seorang wirakop. Sehingga wirakoperasi dapat dijadikan sebagai sarana mengembangkan usaha dengan sifat koperasi (Baga 2003). Wirakop merupakan orang yang memiliki prinsip koperasi dalam mengembangkan suatu bisnis (Hendar 2010). Wirakop sangat dibutuhkan

\footnotetext{
${ }^{3}$ Notulen Rapat Koordinasi Dewan Kelapa Indonesia (Dekindo) dengan Instansi Terkait tanggal 9-11 November 2009 [internet]. [Diunduh pada 4 mei 2014]. Tersedia pada: http://kelapaindonesia2020.wordpress.com/organisasi/dewankelapa-indonesia/notulen-rakor-dekindo/
} 
sebagai perantara antara petani-petani yang memiliki produksi kelapa yang relatif sedikit dan usaha pengelolaan tempurung kelapa. Adanya sistem wirakoperasi yang diterapkan membuat pembangunan usaha berpegang teguh pada prinsip koperasi, yaitu mengutamakan anggota (Baga 2011). Para anggota ini dapat bekerja secara bersama dan terakumulasi dalam mengelola produk kelapa agar mendapatkan harga jual yang lebih kompetitif dibandingkan dengan menjual secara individu. Tidak hanya itu dengan sistem wirakoperasi maka komoditas penting ini dapat menembus pasar ekspor dengan tata cara dan alur bisnis yang benar dan menguntungkan.

Perencanaan bisnis ini diperlukan oleh seorang wirakop untuk menjadi pedoman dalam pelaksanaan bisnis yang akan dijalankan. Penyusunan sebuah rencana bisnis merupakan satu tahap penting dalam pendirian setiap bisnis (Suharyadi et al 2007, Pinson 2007). Dalam mendirikan suatu usaha diperlukan rencana yang baik. Dengan perencanaan yang baik, keuntungan yang akan dicapai dapat diperkirakan dan hambatan yang mungkin akan dihadapi dapat diantisipasi. Rencana yang telah dibuat tersebut dapat membuat seorang wirakop memiliki gambaran yang jelas dan tegas terhadap sesuatu yang akan dikerjakan.

Berdasarkan uraian di atas, maka dapat dirumuskan permasalahan sebagai berikut :

1. Tahapan apa saja yang harus dilakukan dalam merancanakan usaha bisnis briket tempurung kelapa berbasis wirakoperasi ?

2. Apakah keuntungan bisnis briket tempurung kelapa dengan menggunakan konsep wirakoperasi di Kabupaten Bogor?

Penelitian ini dilaksanakan dengan harapan dapat mencapai tujuan sebagai berikut:

1. Merumuskan tahapan dalam merencanakan usaha bisnis briket tempurung kelapa berbasis wirakoperasi.

2. Menganalisis keuntungan yang dapat diperoleh pada usaha briket tempurung kelapa yang berbasis wirakoperasi.

\section{Ruang Lingkup Penelitian}

Penelitian ini membahas mengenai peluang dan potensi usaha briket dari tempurung kelapa yang berbasis wirakoperasi. Perencanaan bisnis yang akan dilakukan berupa pengolahan limbah tempurung kelapa menjadi briket yang disesuaikan dengan permintaan pasar luar negeri. Data yang digunakan untuk mengestimasikan input diperoleh dari data produksi kelapa di beberapa kecamatan di Kabupaten Bogor. Pembahasan dalam perencanaan bisnis ini hanya mencakup bisnis briket tempurung kelapa yang diasumsikan sebagai salah satu unit usaha milik koperasi. Tidak dijelaskan secara lebih rinci mengenai anggaran untuk mengadakan petani dan sosialisasi kepada petani karena proses ini di bawah manajemen koperasi, sehingga masuk dalam keuangan koperasi pula. Perencanaan ini akan membahas beberapa aspek seperti aspek pasar, aspek teknis dan produksi, aspek operasional, 
aspek kerjasama kooperatif, aspek risiko, dan aspek keuangan.

\section{METODE PENELITIAN Waktu dan Tempat Penelitian}

Penelitian ini dilakukan di beberapa kecamatan yang merupakan tempat penghasil kelapa terbesar di Kabupaten Bogor, seperti Leuwiliang, Cibungbulang, dan Ciampea. Pemilihan lokasi dipilih secara sengaja atau purposive. Kegiatan penelitian dan pengumpulan data dilakukan selama bulan Desember 2014 hingga Maret 2015.

\section{Jenis dan Sumber Data}

Jenis data yang digunakan dalam penelitian ini adalah data primer dan data sekunder. Data primer diperoleh melalui wawancara langsung dengan pihak-pihak terkait, diantaranya Unit Pelaksana Teknis Daerah (UPTD), petani, Badan Penyuluhan Pertanian, Perikanan, dan Kehutanan (BP3K), pengusaha arang, dan pengusaha briket. Selain itu juga dilakukan tinjauan lapang pada CV Mandiri Globalindo di Bekasi sebagai perusahaan penghasil briket tempurung kelapa. Sedangkan data sekunder diperoleh melalui literatur, jurnal maupun laporan hasil penelitian, laporan hasil seminar, buku-buku, internet serta data dari instansi terkait yaitu Badan Penyuluhan Pertanian Kabupaten Bogor, Badan Pusat Statistik, Kementrian Perindustrian dan Perdagangan Republik Indonesia, dan Dinas Pertanian Provinsi Jawa Barat.

\section{Metode Analisis Data}

Pengolahan data yang dilakukan meliputi analisis aspek non finansial dan aspek finansial. Dalam aspek non finansial terdiri atas aspek rencana pasar dan pemasaran, rencana teknik dan teknologi, rencana manajemen dan organisasi, rencana risiko. Sedangkan pada aspek finansial terdiri atas proyeksi laporan keuangan dan kriteria kelayakan investasi. Selain itu juga dilakukan analisis politik ekonomi,sosial, teknologi, lingkungan serta analisis situasi bisnis menggunakan porter's five force.

\section{ANALISIS SITUASI BISNIS Analisis PESTE}

Analisis PESTE merupakan analisis faktor eksternal dari organisasi bisnis yang memengaruhi kesuksesan bisnis secara keseluruhan. Faktor yang masuk dalam analisis PESTE adalah politik, ekonomi, sosial, teknologi, dan lingkungan.

\section{Politik}

Tahun 2015 merupakan momen yang sangat bagus untuk melakukan sebuah permulaan di dunia bisnis. Dengan dicanangkannya program masyarakat ekonomi ASEAN membuat beberapa pihak baik pemerintah maupun swasta memberikan kredit khusus untuk mensukseskan program MEA 2015. Banyak seminar-seminar yang diadakan terutama dikalangan akademi yang mencoba memberikan motivasi untuk menjadi salah satu produsen dalam MEA 2015. 


\section{Dinamika Ekonomi}

Jumlah pengangguran di Indonesia juga terus menurun dari tahun 2006 hingga tahun $2014^{4}$. Berkurangnya jumlah pengangguran akan mengakibatkan persaingan yang diperkirakan akan terjadi dalam pemerolehan tenaga kerja ditambah dengan besarnya upah minimum regional di wilayah Bogor yang meningkat menjadi Rp 2590000 dapat menjadi faktor penghambat berkembangnya bisnis. Kemudian, inflasi yang terjadi pada tahun 2015 kuarter 3 cukup tinggi yaitu sebesar 7.15 persen $^{5}$. Inflasi yang terjadi membuat mata rupiah melemah. Apabila mata uang melemah, maka dapat menguntungkan bagi bisnis yang berbasis ekspor. Hal ini karena nilai riil uang yang diterima dalam bentuk dolar akan bernilai tinggi, inilah yang akan terjadi pada bisnis briket berbasis ekspor yang akan direncanakan.

\section{Sosial}

Dari segi sosial, masyarakat bogor di beberapa daerah memang sudah mengenal dan menjalankan koperasi maupun kelompok tani, terutama di beberapa kecamatan yang digunakan menjadi objek penelitian. Hal ini akan memudahkan dalam mensosialisasikan rencana program bisnis briket tempurung kelapa ini kepada para petani. Selain itu, petani-petani yang sudah mengenal koperasi maupun kelompok tani sebelumnya juga diduga memiliki rasa kebersamaan dan sepenanggungan yang tinggi, sehingga dapat memperkuat usaha yang berlandaskan koperasi tersebut. Akan tetapi belum terdapat kelompok tani maupun koperasi yang memproduksi briket, sehingga penjelasan terkait produk harus lebih diperjelas. Hal ini juga akan menjadi peluang bisnis karena belum ada pesaing usaha dibidang ini.

\section{Teknologi}

Teknologi yang digunakan dalam pembuatan briket tempurung kelapa sudah maju. Hal ini karena dalam proses pembuatannya sudah menggunakan alatalat modern yang dapat dipesan ke pada salah satu perusahan di Jogjakarta, yaitu Rumah Mesin. Alat-alat yang digunakan sebelumnya dapat dipesan melalui dengan kapasitas produksi yang dibutuhkan. Pemesanan trsebut dapat dilakukan secara online sehingga akan memudahkan dan mengurangi biaya transaksi.

\section{Lingkungan}

Apabila dilihat dari lingkungan alam, maka usaha briket ini tidak mencemari lingkungan. Hal ini karena tidak ada limbah yang dihasilkan yang dapat merusak lingkungan. Selain itu, pelatihan pembuatan arang yang diperoleh petani dari pihak koperasi juga mengguanakan sistem uap terkondensasi, sehinga uap pembuatan arang hanya kan menjadi asap cair dan tidak akan mencemari udara.

\section{Analisis Industri}

Analisis industri merupakan evaluasi dari persaingan usaha yang dialami oleh suatu organisasi dalam lingkup usaha.

\footnotetext{
${ }^{4}$ Anonim. Indonesia Unemployed Persons. [Internet]. [Dapat diakses pada :

http://www.tradingeconomics.com/indonesia/unemployed-persons].

${ }^{5}$ Anonim. Indonesia Inflation Rate. [Internet]. [Dapat diakses pada :

http://www.tradingeconomics.com/indonesia/inflation-cpi].
} 
Porter's Five Force merupakan cara yang efektif dalam menganalisis situasi bisnis (Rathner, 2014). Dalam Porter's Five Force terdapat lima yang memengaruhi bisnis sukses dalam suatu organisasi, antara lain ancaman pendatang baru, ancaman dari produk pengganti, posisi tawar pembeli, posisi tawar dari supplier, dan tantangan kompetisi pada bisnis yang sudah ada

\section{Posisi Tawar Suppliers}

Posisi tawar dari suppliers biasanya akan dipengaruhi oleh jumlah produsen dalam industri. Dalam industri briket, terutama briket tempurung kelapa di Indonesia diduga masih belum banyak produsennya ataupun rata-rata produsen belum memiliki produktivitas yang tinggi. Hal ini dibuktikan dengan belum tercatatnya briket tempurung kelapa sebagai produk ekspor tersendiri. Akan tetapi, target dari pemasaran briket yang direncanakan adalah ekspor, sehingga pesaing tidak hanya datang dari dalam negeri namun juga dari luar negeri. Sehingga produsen total dari industri briket banyak, bila dilihat dari daftar pengekspor briket diseluruh dunia (UN Comtrade, 2015). Sehingga dapat disimpulkan bahwa posisi tawar produsen briket tidak tinggi.

\section{Posisi Tawar Konsumen}

Posisi tawar konsumen dipengaruhi oleh jumlah konsumen dalam industry. Dalam Industri briket tempurung kelapa posisi tawar konsumen juga tidak tinggi karena jumlah konsumen briket dari seluruh dunia yang banya dengan jumlah permintaan yang besar (UN Comtrade, 2015).

\section{Ancaman Produk Pengganti}

Ancaman produk pengganti dari bisnis briket tempurung kelapa adalah jenis-jenis briket yang terbuat dari bahan baku lainnya, seperti briket dari sampah, dedaunan, serbuk kayu, dan sebagainya. Akan tetapi terdapat keunggulan dari prouk briket yang menggunakan bahan baku tempurung kelapa dibandingkan briket yang menggunakan bahan baku lainnya, yaitu niali kalor yang dihasilkan lebih tinggi (Pari et al 2012). Walaupun memang harga briket yang terbuat dari dedaunan relatif lebih murah. Hal ini karena bahan baku yang digunakan lebih murah.

\section{Ancaman Pendatang Baru}

Apabila hambatan masuk industry rendah maka akan banyak perusahaan baru yang akan memasuki industry, sehingga mengakibatkan kejenuhan pasar. akan tetapi terdapat hambatan utama untuk masuk industri briket seperti biaya yang dibutuhkan. Modal yang dibutuhkan dalam menjalankan bisnis ini cukup besar. Selain itu bahan baku juga dapat menjadi hambatan apabila akan didirikan pada daerah-daerah yang bukan merupakan sentra kelapa. Hal ini juga menjadi hambatan bagi para pengusaha Indonesia karena hasil produksi kelapa Indonesia memenag besar, akan tetapi sebagian besar berasal dari perkebunana rakyat. Perkebunan rakyat yang dimaksud adalah produksi yang dihasilkan oleh petani kelapa secara individu. Sedangkan petani kelapa Indonesia rata-rata hanya memiliki 5-10 pohon, sehingga akan sulit untuk mendapatkan tempurung kelapa dalam jumlah yang besar. Akan tetapi rencana usaha yang akan dijalankan 
menggunakan konsep wirakoperasi, sehingga akan memudahkan dalam melewati hambatan tersebut.

\section{Persaingan Bisnis yang Sudah Ada dalam Industri}

Persaingan bisnis yang sudah ada dalm indutri cukup tinggi. Hal ini dibuktikan engan banyaknya jumlah produsen, baik di dalam maupun luar negeri. Pada tahun 2015, perusahaan briket tempurung kelapa sebanyak 60 perusahaan $^{6}$. Selain itu, pada tahun 2014 terdapat 56 negara pengekspor briket tempurung kelapa (UN Comtrade, 2014).

\section{RENCANA BISNIS}

\section{Asumsi Dasar}

Input yang diperoleh dari petani kelapa di Kabupaten Bogor yaitu dari Kecamatan Leuwiliang, Leuwisadeng, Pamijahan, Cibungbulang, Ciampea, Kelapa Nunggal dan Rumpin yang jumlahnya kurang lebih 1454 ton kelapa per bulan. Lokasi ini dipilih karena merupakan memiliki hasil produksi yang paling besar di Kabupaten Bogor seperti yang dipaparkan pada Lampiran 2 sebelumnya. Badan hukum yang digunakan adalah sudah berdiri, yaitu Koperasi Sejahtera Bersama. Hal ini didasarkan oleh informasi yang didapat bahwa Koperasi Sejahtera Bersama sedang mencari usaha yang dapat dikembangkan.

Menurut Sutojo (2000) dalam aspek teknis dan teknologi juga terdapat penentuan kapasitas produksi. Penentuan estimasi jumlah produksi masa kini dan perkembangannya di masa yang akan datang dilakukan dengan melakukan perkiraan pada permintaan masa kini dan permintaan yang akan datang (Sukirno et al 2006). Kapasitas produksi pabrik dalam satu kali produksi memerlukan 2 ton tepung arang kelapa. Oleh karena itu dibutuhkan kurang lebih 6 ton tempurung kelapa, karena tempurung kelapa yang telah dikarbonisasi akan menyusut menjadi 30 persen dari berat awal. Dalam satu bulan produksi akan dilakukan sebanyak 20 kali, dengan asumsi satu minggu terdapat 5 hari kerja. Dengan kapasitas tersebut maka dibutuhkan tempurung kelapa sebanyak 132 ton per bulan. Namun tempurung kelapa ini akan diolah menjadi arang oleh kelompok tani di bawah bimbingan koperasi, sehingga bahan baku yang masuk pada unit usaha briket ini sudah berupa arang.

Akan tetapi karena pada awal berjalannya bisnis ini diasumsikan efisiensi akan produksi yang tercapai hanya 97 persen, maka pada tahun pertama rata-rata briket yang dapat dihasilkan hanya 1.8 ton per hari. Kemudian ditahun kedua dan seterusnya efisiensi yang dicapai dapat mencapai 100 persen sehingga dapat mencapai 2 ton per harinya

Dana yang digunakan untuk menjalankan bisnis ini diasumsikan berasal dari investor dengan pembagian keuntungan sebanyak 30 persen dari laba yang diperoleh koperasi. Dana pinjaman ini rencananya dapat dikembalikan dalam waktu 6 tahun. Asumsi proyeksi keuangan dibuat 10 tahun, mengikuti umur ekonomis dari mesin Pajak dihitung berdasarkan Peraturan Pemerintah

\footnotetext{
${ }^{6}$ http://www.indotrading.com/showcase/arang-batok-kelapa. [Internet]
} 
Nomor 46 Tahun 2013 Pasal 3 Ayat 3 dan 4, serta dirinci pada pasal 17 ayat 2a [(0.25- (0.6 M/penghasilan kotor) $) \mathrm{x}$ PKP]. Selain itu pajak pertambahan nilai yang ditetapkan untuk briket adalah nol persen sesuai dengan ketetapan Menteri Keuangan No 2369/KM.4/2013 tentang penetapan harga ekspor untuk perhitungan bea keluar. Hal ini karena bea keluar hanya dikenakan untuk produk CPO dan turunannya, karet, biji kakao dan kulit.

\section{Rencana pada Aspek Pasar dan Pemasaran}

\section{Potensi Pasar Briket}

Potensi pasar dari usaha briket ini dapat diihat dari permintaan akan briket yang terus meningkat setiap tahunnya, seperti yang terlihat pada Lampiran 4 . Tabel pada lampiran tersebut menunjukan peningkatan ekspor briket dari tahun 2013 ke tahun 2014. Sedangkan pada tahun 2015 untuk 3 bulan yang telah terhitung saja nilainya 40 persen dari nilai total ekspor pada thun 2014, sehingga di proyeksikan pada tahun 2015 jumlah briket yang di ekspor juga akan meningkat kembali. Pendekatan ekspor dari perusahaan di India ini dilakukan untuk memprediksi permintaan dari briket di pasar internasional. Dengan nilai ekspor yang terus meningkat, maka menjelaskan bahwa permintaan akan briket juga meningkat. Data dari perusahaan India ini digunakan karena data khusus briket di Indonesia tidak dapat ditemukan.

\section{Strategi Pemasaran}

\section{a. Segmenting}

Segmentasi dari produk ini merupakan pabrik-pabrik yang menggunakan produk ini sebagai bahan bakar, importir dan industry wholesale yang akan menyalurkannya kepada masyarakat di negara tersebut. Pengelompokan segmentasi berdasarkan geografis adalah perusahaan pengimpor di luar negeri.

\section{b. Targeting}

Target pasar adalah negara Jepang. Hal ini karena permintaannya yang paling banyak seperti yang terlihat pada Tabel 1. Selain itu, dalam rangka memperluas pasar maka akan dilakukan pula promosi pada 5 negara dengan permintaan terbanyak selain Jepang, yaitu Irlandia, Prancis, Cina,dan Republik Ceko.

\begin{tabular}{|c|c|c|}
\hline Negara & Vurotito & Nila (UICS) \\
\hline Japan & 94489000 & 32266880 \\
\hline Irlandia & 68002011 & 14599534 \\
\hline Prancis & 43513246 & 9803737 \\
\hline Cina & 37528737 & 3571670 \\
\hline Republik Ceko & 27230478 & 3716504 \\
\hline Inggi & 14381913 & 3249494 \\
\hline Polan & 13379830 & 1702620 \\
\hline Afrika & 10258822 & 1218759 \\
\hline Slovakia & 7851364 & 1516355 \\
\hline Negara-negara lainnya & 18114120 & 8340998 \\
\hline Total & 334749521 & 79986551 \\
\hline
\end{tabular}

\section{c. Positioning}

Briket tempurung kelapa merupakan produk akhir yang siap dikonsumsi oleh konsumen secara langsung untuk bahan bakar industri, rokok sisha, dan penghangat ruangan. 


\section{d. Marketing Mix}

Marketing mix atau bauran pemasaran ini terdiri atas produk, harga, promosi, dan tempat (Downey dan Ericson dalam Asmarantaka 2012).

a) Produk

Produk dari usaha ini adalah briket tempurung kelapa yang merupakan produk yang siap pakai. Briket yang dihasilkan akan berbentuk kubus. Produk briket yang dihasilkan mempunyai sisi persegi dengan panjangan masing-masing 2.5 $\mathrm{cm}$ dan tinggi $1.5 \mathrm{~cm}$. Briket dibungkus plastik dan dimasukan dalam kemasan dengan berat satu kilogram untuk satu kemasannya. Dalam satu kemasan terdapat 120 pcs briket.

b) Harga (Price)

Harga jual dari produk ini adalah sebesar Rp11 829. Harga ini ditetapkan berdasarkan pertimbangan harga dunia dan juga keuntungan yang dapat diperoleh. Menurut International Trade Statistic Database (UN Comtrade, 2015), harga dunia untuk briket pada tahun 2014 adalah Rp12 196. Akan tetapi karena usaha briket ini bukan merupakan market leader, maka harga yang diterapkan akan lebih rendah dari harga dunia, namun dengan tetap memertimbangkan harga pokok dan juga laba yang diinginkan. Oleh karena itu harga yang ditetapkan hanya 97 persen dari harga dunia c) Promosi (Promotion)

Pertama usaha ini akan membuat web untuk memberikan info terkait produk secara terperinci. Kemudian, akan memasang beberapa iklan di internet untuk menawarkan produk ini. Selain menggunakan media internet, promosi yang dilakukan juga mengirimkan surat penawaran kepada perusahaanperusahaan yang membutuhkan briket, asosiasi importir Jepang, seperti Japan External Trade Organization (JETRO), kemudian mengirim juga ke atase perdagangan di luar negeri, badan pengembangan ekspor nasional, serta kantor Indonesia Trade Promotion Centre di Jepang sesuai yang disarankan pada Direktorat Jenderal Pegembangan Ekspor Nasional (2013)

d) Tempat (Place)

Pabrik pengolahan terletak di Jalan Raya Sinagar Desa Cihideung Udik, Ciampea, Bogor. Lokasi pabrik ini dipilih karena akses yang mudah dan strategis jika dilihat dari tempat pengumpulan bahan baku yang terletak di daerah Bogor Barat.

\section{Rencana pada Aspek Teknik dan Teknologi}

\section{Rencana Ketersediaan Bahan Baku}

Usaha ini menggunakan bahan baku berupa arang batok kelapa yang dibuat oleh pengrajin arang yang juga sebagai anggota koperasi. Nantinya para petani penghasil kelapa ini diajari cara pembuatan arang batok kelapa, sehingga 
mereka dapat secara berkelompok membuat arang batok kelapa tersebut. Bahan baku berupa arang kelapa diperoleh dari para petani di wilayah Bogor, khususnya di Kecamatan Leuwiliang, Leuwisadeng, Pamijahan, Cibungbulang, Ciampea, Kelapa Nunggal, dan Rumpin. Koperasi tidak hanya membeli arang tempurung kelapanya saja, namun juga keseluruhan bagian dari buah kelapa. Para petani yang akan menyetorkan hasil buah kelapanya harus terlebih dahulu memisahkan buah kelapa menjadi beberapa bagian, seperti daging, air, tempurung, dan sabutnya. Nantinya koperasi akan membantu dalam menjualkannya. Bagian tempurung nantinya akan diolah oleh kelompok tani menjadi arang, kemudian dijual ke unit usaha briket tempurung kelapa ini yang merupakan milik koperasi juga. Adapun poses pengumpulan bahan baku dapat dilihat pada Lampiran 5

Bahan baku yang berupa arang tempurung kelapa dari kelompok tani yang dibutuhkan adalah sebanyak 2 ton per harinya. Selain tempurung kelapa dibutuhkan juga kanji yang digunakan sebagai perekat dari briket. Kanji yang digunakan adalah sebanyak 2.5-3 persen dari berat tepung karbon. Oleh karena itu kanji yang digunakan kurang lebih 50 kg.

\section{Rencana Perumusan Standar Mutu} Input dan Output

\section{a. Standar Mutu Output}

Tujuan utama dari penjualan briket ini adalah pasar ekspor, maka standar mutu produk juga harus mengikuti memperhatikan permintaan konsumen. Menurut CV Mandiri Global- indo mutu produk yang biasa diinginkan oleh para pembeli dapat dilihat di Tabel 2.

Tabel 2. Standar Mutu Briket yang Sering Diinginkan Pembeli

\begin{tabular}{lc}
\hline Parameter & Nilai \\
\hline Kadar air (\%) & $5-8$ \\
Kadar abu (\%) & $3-8$ \\
Nilai kalor (kal /g) & 7000 \\
Kadar sulfur (\%) & 0.01 \\
\hline Sumber : CV Mandiri Globalindo
\end{tabular}

\section{b. Standar Mutu Input}

Input yang digunakan adalah arang tempurung kelapa yang kadar kelembabannya tidak lebih dari 10 persen dan kadar abu harus dibawah 3 persen. Pengecekan dilakukan dengan cara menyangrai arang tersebut, setelah selesai disangrai maka dilakukan penimbangan ulang terhadap arang tersebut. Penyusutannya tidak boleh lebih dari 20 persen berat awal. Inilah arang yang ideal yang digunakan sebagai bahan baku.

\section{c. Rencana Proses Produksi}

Proses produksi yang dilakukan untuk menghasilkan briket yaitu : a) penggilingan arang, b) pengayakan tempurung arang, c) pencampuran tepung arag dengan lem kanji, d) pencetakan, d) pengeringan dengan oven, dan e) pengemasan.

\section{Rencana Teknologi yang Digunakan}

Beberapa teknologi modern diterapkan dalam proses produksi pada usaha ini, seperti penggunaan mesin penghancuran dan penghalusan batok (crusher). Setelah proses penghancuran akan dilanjutkan dengan proses pencampuran antara 
tepung arang dangan kanji menggunakan mesin mixer. Kemudian dilanjutkan dengan penggunaan mesin pencetak dan oven.

\section{Perencanaan Tata Letak dan Lokasi}

Lokasi pendirian usaha rencananya akan terletak di Jalan Raya Sinagar Desa Cihideung Udik, Ciampea, Bogor. Rencananya tanah yang akan digunakan untuk usaha seluas $266.5 \mathrm{~m}^{2}$. Bangunan yang akan didirikan akan berada dalam satu atap, sehingga hanya dipisahkan oleh beberapa tembok penyekat. Secara garis besar area bangunan terbagi menjadi dua, yaitu area produksi dan area kantor seperti gambar pada Lampiran 6. Area produksi terdiri atas area gudang bahan baku, gudang produk jadi, area penggilingan, area pengayakan, area pencampuran, area pencetakan, area pengemasan, dan ruang oven. Dalam perencanaan tata ruang akan tetap memerhatikan fleksibilitas pabrik demi kemungkinan perluasan pada masa yang akan datang seperti menurut Hadiguna (2009).

\section{Rencana Organisasi dan Sumber Daya Manusia}

\section{Bentuk Organisasi}

Koperasi merupakan jenis badan usaha yang dipilih untuk menaungi usaha briket. Hal ini karena tujuan utama dari pendirian bisnis adalah untuk membantu para petani dalam meningkatkan nilai tambah tempurung kelapa yang sekaligus diharapkan dapat meningkatkan perekonomian para petani itu sendiri, sehingga usaha ini didirikan atas dasar kebersamaan yang mementingkan ke- pentingan bersama seperti konsep koperasi.

\section{Struktur Organisasi}

Struktur organisasi yang akan dibentuk dalam unit usaha briket ini seperti koperasi pada umumnya dengan posisi tertinggi adalah rapat umum anggota (RUA), diikuti dengan pengawas, dan pengurus. Yang membedakan struktur organisasi koperasi ini dengan yang lain adalah beberapa posisi yang kewenangannya dibawah pengurus seperti koordinator usaha, manajer produksi, manajer keuangan, dan manajer pemasaran seperti yang tergambar dalam Lampiran 7.

\section{Upah dan Gaji}

Adapun rincian upah dan gaji tenaga kerja dalam usaha briket dapat dilihat pada Lampiran 3.

\section{Rencana Kemitraan}

Pola kemitraan yang rencanya akan dijalankan adalah pola kemitraan vertikal. Hal ini karena kemitraan yang akan dibangun terkait dengan kemitraan dalam penyediaan bahan baku dan kemitraan dalam penyediaan modal usaha. Kemitraan dalam penyediaan bahan baku akan dilakukan dengan para petani kelapa yang ada di Kabupaten Bogor. Para petani dari beberapa kecamatan yang telah dipilih kemudian akan dikumpulkan dan diajak untuk membuat kelompok tani, kemudian dilanjutkan dengan pembentukan gabungan kelompok tani. kemudian proses berikutnya adalah mengajak para petani ini untuk bersama-sama membangun unit usaha briket. Sehingga kerjasama yang dilakukan dengan petani menjadikan petani sebagai pemasok bahan baku dari usaha briket dan juga sebagai anggota 
Tabel 3. Perbedaan Sesudah dan Sebelum Usaha Briket Tempurung Kelapa Berbasis Wirakoperasi

\begin{tabular}{llll}
\hline \multicolumn{1}{c}{ Uraian } & $\begin{array}{l}\text { Sebelum adanya } \\
\text { usaha briket }\end{array}$ & $\begin{array}{l}\text { Usaha briket tanpa konsep } \\
\text { kewirakoperasian }\end{array}$ & $\begin{array}{l}\text { Usaha briket dengan konsep } \\
\text { kewirakoperasian }\end{array}$ \\
\hline $\begin{array}{l}\text { Arang } \\
\text { tempurung } \\
\text { kelapa }\end{array}$ & $\begin{array}{l}\text { Belum dapat } \\
\text { dihasilkan petani }\end{array}$ & Rp 4 000 per kg & $\begin{array}{l}\text { Rp } 5000 \text { per kg, namun petani } \\
\text { akan mendapatkan tambahan } \\
\text { uang dari sisa bagi hasil usaha } \\
\text { briket }\end{array}$ \\
\hline Sistem jual & $\begin{array}{l}\text { Tidak menjual } \\
\text { arang karena } \\
\text { petani belum } \\
\text { dapat }\end{array}$ & $\begin{array}{l}\text { Di jual dari petani ke } \\
\text { pengumpul }\end{array}$ & $\begin{array}{l}\text { Melalui kelompok tani ke } \\
\text { koperasi }\end{array}$ \\
& memproduksinya & & \\
\hline $\begin{array}{l}\text { Pelatihan } \\
\text { mengenai } \\
\text { budidaya kelapa } \\
\text { yang baik }\end{array}$ & Belum ada & Tidak ada & Ada \\
\hline Kepastian pasar & Tidak ada & Belum ada kepastian & $\begin{array}{l}\text { Adanya kepastian pasar karena } \\
\text { adanya kemitraan yang telah } \\
\text { pasar karena belum ada } \\
\end{array}$ \\
& & $\begin{array}{l}\text { kontrak antara pengusaha } \\
\text { dan petani secara individu } \\
\text { koperasi }\end{array}$ \\
\hline
\end{tabular}

koperasi. dalam pola kemitraan ini akan saling menguntungkan semua pihak yang dijelaskan gambar dalam Lampiran 8.

Usaha briket yang dijalankan dengan berlandaskan prinsip koperasi dengan menggunakan sistem kewirakoperasian ini diharapkan mampu memberikan banyak kemajuan dalam berbagai aspek. Adapun manfaat yang diharapkan dapat tercapai dengan adanya usaha ini dapat dilihat pada Tabel 3.

\section{Rencana Manajemen Risiko}

Menurut Fahmi (2010), pada umumnya risiko yang mungkin terjadi pada suatu usaha terbagi menjadi dua, yaitu risiko murni dan risiko spekulatif.

\section{Risiko Murni}

\section{a. Risiko Aset Fisik}

Risiko aset fisik merupakan risiko mengenai kerusakan pada aset yang dapat mengahambat jalannya produksi. Pada CV Mandiri Globalindo terkadang proses produksi terhenti akibat mesin yang rusak. Untuk menghindari terjadinya masalah tersebut maka akan dilakukan pengecekan alat dan biaya perawatan alat atau service untuk setiap bulannya.

\section{b. Risiko Kecelakaan Karyawan}

Risiko terjadinya kecelakaan pada proses produksi memang tidak dapat dihindari, seperti halnya kecelakaan kebakaran yang terjadi karena kelalaian karyawan dalam mengoperasikan mesin oven pada CV Mandiri Globalindo. Oleh karena itu, untuk menghindarinya perlu diterapkan kedisiplinan dalam proses produksi. Kedisiplinan yang diterapkan agar karyawan menjalankan proses produksi sesuai dengan SOP produksi. 
2. Risiko Spekulatif

\section{a. Risiko Produksi}

Sangat memungkinkan untuk tidak menyerap semua tempurung kelapa yang dihasilkan oleh para petani karena mutunya yang tidak memenuhi kriteria bahan baku yang dibutuhkan. Hal ini akan berpengaruh kepada kuantitas yang dapat diterima belum mencukupi kebutuhan akan bahan baku. Oleh karena hal ini juga dapat menjadi risiko yang mengancam kontinuitas usaha briket. Untuk itu dibutuhkan cara untuk mengatasi kemungkinan ini yaitu dengan cara melakukan pembimbingan dan pengontrolan secara berkala akan proses produksi arang yang dilakukan oleh kelompok tani agar tetap sesuai dengan SOP pembuatan arang yang baik.

Pengecekan bahan baku berupa arang juga perlu untuk dilakukan sebelum menggunakan arang pada proses produksi. Akan tetapi apabila produk yang sudah jadi masih belum memenuhi standar output, maka produk tersebut di hancurkan lagi untuk diproduksi ulang dengan penambahan bahan baku yang baik dengan pengurangan porsi penggunaan kanji.

\section{b. Risiko Pasar}

a) Pemutusan kontrak pembelian

Dalam suatu kerjasama yang dilakukan dengan pihak pembeli dapat terjadi risiko yang tidak dapat diduga sebelumnya, yaitu pemutusan hubungan kerjasama. Hal ini bisa dilakukan akibat ketidakpuasan konsumen dengan produk maupun pelayanan yang diberikan oleh produsen, mungkin dapat berupa keterlambatan pengiriman maupun ketidaksesuaian mutu. Oleh karena itu, diperlukan antisipasi terhadap kemungkinan ini dengan menjaga kualitas mutu produk dan juga menjaga kepercayaan terhadap waktu pengiriman. Waktu pengiriman akan tepat jika dilakukan manajemen waktu dalam produksi yang baik. Dengan adanya jadwal produksi yang terencana maka dapat memperkirakan pesanan yang dapat diterima dan ketepatan waktu pengiriman akan tercapai. Selain itu juga perlunya dibuat kontrak yang jelas terkait ketentuan kerjasama jual beli, sehingga pihak pembeli tidak dapat memutuskan hubungan kerja sama atas alasan yang tidak jelas.

b) Produk ditolak konsumen

Target pasar produk ini adalah pasar ekspor, untuk itu memang diperlukan spesifikasi dan kualitas yang baik untuk dapat diterima. Oleh karena itu akan muncul risiko penolakan produk yang telah dihasilkan karena dianggap tidak sesuai dengan spesifikasi yang diinginkan oleh konsumen. Untuk itu perlu dilakukan pencegahan dengan mencari informasi yang jelas mengenai spesifikasi yang diinginkan oleh konsumen, sehingga dapat diperkirakan apakah nantinya produk briket yang dihasilkan dapat memenuhi kriteria atau tidak. Kemudian juga dibutuhkan kontrol terhadap kandungan 
produk yang dapat dilakukan dengan pengecekan kandungan briket secara teratur pada laboratorium berbayar (PT Sucofindo).

c) Risiko harga

Harga yang berlaku dapat berubahubah sewaktu-waktu, untuk itu harga juga merupakan risiko dalam usaha briket ini yang dapat merugikan koperasi. Oleh karena itu, langkah preventif yang dapat dilakukan yaitu melakukan kontrak kerjasama dengan menetapkan nilai harga yang menjadi kesepakatan bersama, sehingga perubahan harga tidak akan mempengaruhi harga jual produk pada konsumen dalam jangka waktu kerjasama yang ditentukan.

\section{Rencana Aspek Finansial}

\section{Rencana Investasi}

Biaya investasi yang dibutuhkan untuk mendirikan usaha briket ini sebesar Rp580 juta. Adapun rincian dari biaya investasi yang dikeluarkan ada pada Lampiran 9.

\section{Biaya Operasional}

Biaya operasional merupakan biaya yang dikeluarkan dalam menopang berjalannya usaha tersebut. Biaya ini terdiri atas biaya variabel dan juga biaya tetap. Biaya variabel yang dibutuhkan pada tahun pertama adalah Rp1.78 miliar. Kemudian pada tahun selanjutnya sekitar Rp3.72 miliar. Rincian biaya variabel dapat dilihat pada Lampiran 10. Sedangkan biaya tetap yang yang dibutuhkan dalam satu bulannya adalah Rp53 juta. Sedangkan biaya tetap yang dibutuhkan dalam satu tahun adalah sekitar Rp636 juta. Adapun rincian biaya tetap yang dikeluarkan dapat dilihat pada Lampiran 11.

\section{Modal awal}

Dalam upaya menjalankan usaha briket ini memerlukan modal awal sebagai pijakan pertama dalam menjalankan berbagai kegiatannya. Modal awal yang diperlukan berupa baiaya investasi pada tahun pertama, biaya tetap dan biaya variabel 1 bulan pada tahun pertama. Biaya variabel dan tetap dalam pertama dimasukan dalam modal awal untuk menjaga kestabilan keuangan pada awal berdirinya bisnis. Hal ini karena pada awal berdirinya bisnis belum tentu semua produk dapat terjual akibat dari belum adanya pelanggan. Modal awal yang dibutuhkan untuk menjalankan usaha briket ini adalah Rp710 juta.

\section{Penerimaan Penjualan}

Jumlah produk akan briket yang mampu dihasilkan pada seiap bulannya adalah 40 ton. Akan tetapi, pada tahun pertama produksi dimulai pada bulan ke tujuh dengan asumsi penjualan 50 persen di bulan ke-7, 60 persen di bulan ke-8, 70 persen pada bulan ke-9, dan penjualan sebesar 75 persen pada bulan ke-10. Sedangkan bulan ke dan bulan ke-11 dan 12 sebesar 80 persen. Kemudian pada bulan pertama semua proses produksi tidak dapat dijalankan karena jadwal produksi yang berurutan dan satu proses membutuhkan satu hari untuk menghasilkan bahan untuk proses selanjutnya seperti pada Lampiran 12. Oleh karena itu, maka total produksi pada tahun pertama hanya sebanyak 25.2 ton. Dengan asumsi penjualan tersebut maka penerimaan yang diperkirakan diperoleh 
pada tahun pertama adalah sekitar Rp1.7 miliar. Pada tahun kedua diasumsikan penjualan 90 persen dari kapasitas produksi sehingga penerimaan sebesar Rp5.1 miliar sedangkan pada tahun ke-3 dan selanjutnya dengan penjualan 100 persen dari kapasitas maka akan mendapatkan penerimaan sebesar Rp5.6 miliar.

\section{Proyeksi Kriteria Investasi}

Proyeksi investasi dapat dilihat dari besarnya Nilai NPV, Gross B/C, dan paybackperiod (Nurmalina et al 2010, Wibowo 2011, Nurhayati 2012, dan Nugraha 2014). Usaha briket tempurung kelapa ini cukup menjanjikan karena pada proyeksi arus kas pada Lampiran 14 diperoleh informasi bahwa nilai NPV sebesar Rp5.1 miliar, karena nilainya lebih besar dari nol maka bisnis ini dikatakan layak. Selain itu terdapat informasi mengenai nilai gross $\mathrm{B} / \mathrm{C}$ sebesar 1.18 yang artinya setiap Rp1 biaya yang dikeluarkan akan memperoleh keuntungan bersih sebesar Rp1.18 dengan paybackperiod selama 2 tahun 8 bulan. Pada setiap kriteria investasi yang dihasilkan menunjukan bahwa bisnis ini layak secara finansial. Oleh karena itu, bisnis ini akan sangat berpotensi untuk dilaksanakan dan dikembangkan.

\section{SIMPULAN DAN SARAN Simpulan}

Rencana usaha briket yang dilakukan meliputi asumsi dasar, rencana pada aspek pasar dan pemasaran, teknis dan teknologi, organisasi dan sumber daya manusia, manajemen risiko, serta finansial. Briket tempurung kelapa merupakan produk yang sangat diminati dan prospektif. Hal ini karena jika dilihat dari permintaannya yang banyak dan cenderung naik. Briket yang rencananya akan dipasarkan ke negara Jepang ini akan dijual dengan harga Rp11 829 untuk 1 kg nya dan tentunya akan disesuaikan dengan nilai dolar dengan asumsi 1 dolar sama dengan Rp13 065.

Usaha briket tempurung kelapa ini akan menguntungkan banyak pihak apabila dilaksanakan dengan berbasiskan kewirakoperasian. Hal ini dapat dilihat dari segi finansial dan nonfinansial. Secara finansial, semua pihak mendapatkan untung berupa bagi hasil dengan besaran investor 20 persen, wirakop 15 persen, petani 25 persen, koperasi 10 persen, dan laba ditahan 30 persen. Akan tetapi, pada tahun ke tujuh persentase bagi hasil berubah karena sudah tidak ada lagi bagi hasil untuk investor, sehingga proporsinya menjadi petani 40 persen, wirakop 25 persen, koperasi 10 persen, dan laba ditahan sebanyak 25 persen. Prospek keuntungan secara finansial juga didukung dengan kriteria investasi yang memenuhi syarat, NPV sebesar Rp5.1miliar, gross $B / C$ sebesar 1.18, payback period 2.8 tahun. Selain itu dari segi nonfinansial dengan adanya bisnis briket berbasis wirakoperasi juga akan meningkatkan pengetahuan dan keterampilan petani kelapa. Hal ini karena para petani kelapa yang menjadi anggota koperasi bisa mendapatkan pelatihan terkait produksi kelapa yang baik, serta keterampilan membuat arang dari batok kelapa. 


\section{Saran}

Berdasarkan hasil penelitian ini, maka terdapat beberapa saran yang perlu diperhatikan. Apabila dilakukan penelitian lebih lanjut, sebaiknya mengkaji lebih dalam terkait pesaing usaha serta menganalisis kekuatan, kelemahan, ancaman dan peluang dalam usaha briket tempurung kelapa berbasis wirakoperasi. Selanjutnya dengan melihat bisnis yang prospektif ini hendaknya dapat membangkitkan jiwa kewirakoperasian pembaca sehingga dapat tertarik untuk melaksanakan bisnis briket tempurung kelapa ini.

Adanya sistem kewirausahaan yang mengikutsertakan petani kelapa sangat disarankan untuk dilakukan dalam pembangunan usaha bisnis briket tempurung kelapa. Hal ini penting dilakukan karena dapat menjaga kestabilan pasokan input arang tempurung kelapa. Selain itu perluasan pemasaran juga perlu untuk dilakukan apabila Jepang sebagai negara yang menjadi target pasar tidak memberikan respon baik atas penawaan yang diberikan. Penawaran terbuka yang dapat dilakukan selain dengan membuat web dan iklan di internet adalah mendaftarkan produk agar dapat mengikuti pameran dagang produk ekspor yang diselenggarakan kementerian perdagangan.

\section{DAFTAR PUSTAKA}

Asmarantaka R.W. 2012. Pemasaran Agribisnis (Agrimarketing). Bogor (ID): Departemen Agribisnis FEM-IPB

Baga L.M. 2003. Peran Wirakoperasi dalam Pengembangan Sistem
Agribisnis Kajian Terhadap Pengembangan Agribisnis Persusuan di Indonesia. Makalah pada Seminar Dwibulanan ISTECS Eropa di Pusat Studi Asia Tenggara di Universitas Frankfurt. Jerman. [Internet]. [Diunduh 2014 Desember 21].Tersedia pada : http://www.geocities.ws/mma5u gm/PeranWirakoperasiDlmAgribi snis.pdf.

Baga L.M. 2011. Profil dan Peran Wirakoperasi dalam Pengembangan Sistem Agribisnis. Jurnal. Dalam Prosiding Seminar Penelitian Unggulan Departemen Agribisnis. Fakultas Ekonomi dan Manajemen. Bogor (ID): Institut Pertanian Bogor

[BPS] Badan Pusat Statistik Kabupaten Bogor. 2013. Luas dan Produksi Perkebunan Rakyat Kabupaten Bogor Menurut Jenis dan Dirinci per Kecamatan. Kabupaten Bogor dalam Angka.

[BPS] Badan Pusat Statistik. 2014. Luas Areal Tanaman Perkebunan Rakyat Menurut Jenis Tanaman, 2000-2013. [Internet]. [Diunduh 2014 Desember 1]. Tersedia ada: http://www.bps.go.id/linkTabelSta tis/view/id/1669

[BPS] Badan Pusat Statistik. 2014. Exim Tanhut All Comodity. Badan Pusat Statistik Republik Indonesia

[BPS] Badan Pusat Statistik. 2015. Luas Areal Tanaman Perkebunan Rakyat Menurut Jenis Tanaman, 2000-2013. File. http://www.bps.go.id/linkTabelSta tis/view/id/1669 [18 Maret 2015] 
[Dekindo] Dewan Kelapa Indonesia. 2009. Notulen Rapat Koordinasi Dewan Kelapa Indonesia (Dekindo) dengan Instansi Terkait tanggal 9-11 November 2009 [internet]. [Diunduh pada 4 Mei 2014]. Tersedia pada: http://kelapaindonesia2020.wordpr ess.com/organisasi/dewan-kelapaindonesia/notulen-rakor-dekindo/

Direktorat Jenderal Pegembangan Ekspor Nasional. 2013. Panduan Menjadi Eksportir. Jakarta : Kementrian Perdagangan republic Indonesia (ID).

Fahmi I. 2010. Manajemen Risiko (Teori, Kasus, dan Solusi). Bandung (ID) : Alfabeta.

Hadiguna RA. 2009. Manajemen Pabrik : Pendekatan Sistem untuk Efisiensi dan Efektivitas. Jakarta (ID):Bumi Aksara.

Hendar. 2010. Manajemen Perusahaan Koperasi. Semarang (ID) : Erlangga.

Nugraha D.Y. 2014. Rencana Pengembangan Agribisnis Daun Kumis Kucing dengan Pendekatan Cooperative Entrepreneur di Bogor [Skripsi]. Bogor : Institut Pertanian Bogor.

Nurmalina R, Tintin S, Arif K. 2010. Studi Kelayakan Bisnis. Bogor (ID): Departemen Agribisnis Fakultas Ekonomi dan Manajemen IPB.

Nurhayati P. 2012. Kelayakan Usaha Pembibitan Domba Melalui Program Kemitraan dan Inkubasi Bisnis dalam Rangka Pemberdayaan Masyarakat di
Kabupaten Bogor. Di dalam : Prosiding Seminar (Penelitian Unggulan Departemen Agribisnis). Bogor (ID): Institut Pertanian Bogor

Pari G, Mahfudin, Jajuli. 2012. Teknologi Pembuatan Arang, Briket Arang dan Arang Aktif serta Pemanfaatannya. Semarang : Kementrian Kehutanan Badan Penelitian dan Pengembangan Kehutanan [Internet]. [Diunduh pada 2014 September 25]. Tersedia pada : http://www.fordamof.org/files/arang-Gustam.pdf.

Pinson L. 2003. Anatomy Of A Business Plan. Jakarta (ID): Canary.

Rathner J.S. 2014. Situational Analysis : Visit Philadelphia. Temple University.

Suharyadi, Arisetyanto N, Purwanto SK, Maman F. 2007. Kewirausahaan (Membangun Usaha Sukses Sejak Usia Muda). Jakarta (ID) : Salemba Empat

Sukirno S et al. 2006. Pengantar Bisnis. Jakarta (ID) : Kencana.

Sutojo S. 2000. Studi Kelayakan Proyek. Jakarta (ID) : PT Pustaka Binaman Pressindo

UN Comtrade (International Trade Statistics Database). 2015. [Internet]. [Diunduh pada 2015 Maret 10]. Tersedia pada: http://contrade.un.org

Wibowo M.I.A. 2011. Rencana Bisnis Industri Manisan Stroberi [Skripsi]. Bogor : Institut Pertanian Bogor 
Lampiran 1. Ekspor Briket dan Produk Tersier Kayu di Indonesia

\begin{tabular}{ccc}
\hline Tahun & Nilai (US\$) & Kuantitas (kg) \\
\hline 2008 & 751914 & 2277801 \\
2009 & 686758 & 2706146 \\
2010 & 569236 & 3160187 \\
2011 & 604227 & 3657225 \\
2012 & 7738936 & 55420080 \\
\hline
\end{tabular}

Sumber : Badan Pusat Statistik (2014)

Lampiran 2. Luas dan Produksi Tanaman Kelapa di Kabupaten Bogor 2012

\begin{tabular}{lcc}
\hline \multirow{2}{*}{ Kecamatan } & \multicolumn{2}{c}{ Kelapa } \\
\cline { 2 - 3 } & Luas (Ha) & Produksi (Ton) \\
\hline Rumpin & 404.10 & 997.65 \\
Leuwiliang & 466.56 & 1059.68 \\
Leuwisadeng & 335.82 & 724.75 \\
Pamijahan & 332.10 & 777.78 \\
Cibungbulang & 463.41 & 983.03 \\
Ciampea & 485.76 & 1167.88 \\
Kalapa nunggal & 367.95 & 923.22 \\
Lainnya & 3870.91 & 9788.81 \\
\hline Total Kabupaten Bogor & 6726.61 & 16208.4 \\
\hline
\end{tabular}

Sumber : Badan Pusat Statistik Kabupaten Bogor 2012

Lampiran 3. Rincian Upah dan Gaji Tenaga Kerja Usaha Briket per Bulan Unit Usaha Tunas Muda

\begin{tabular}{lrrr}
\hline \multicolumn{1}{c}{ Posisi } & $\begin{array}{c}\text { Biaya } \\
\text { satuan } \\
\text { (Rp000) }\end{array}$ & Jumlah & $\begin{array}{r}\text { Jumlah } \\
\text { biaya } \\
\text { (Rp000) }\end{array}$ \\
\hline Koordinator usaha & 5000 & 1 & 5000 \\
Manajer keuangan & 3750 & 1 & 3750 \\
Manajer produksi & 4000 & 1 & 4000 \\
Manajer pemasaran & 3800 & 1 & 5180 \\
Tenaga kerja produksi bagian penggilingan & 2590 & 2 & 5180 \\
Tenaga kerja produksi bagian pengayakan & 2590 & 2 & 5180 \\
Tenaga kerja produksi bagian pengadukan & 2590 & 2 & 5180 \\
Tenaga kerja produksi bagian pencetakan & 2590 & 2 & 5180 \\
Tenaga kerja produksi bagian pengeringan & 2590 & 2 & 5180 \\
dengan oven & & & 3000 \\
Total upah tenaga kerja pengangkutan & 300 & $10 \times$ xorongan & 2590 \\
Penjaga malam & 2590 & 1 & 800 \\
Supir & 100 & $8 x$ kepergian & 48840 \\
Total & & & \\
\hline
\end{tabular}


Lampiran 4. Ekspor Briket Tempurung Kelapa di India

\begin{tabular}{|c|c|c|c|}
\hline Tahun & Bulan & Kuantitas (Kg) & Kuantitas per tahun (Kg) \\
\hline \multirow{3}{*}{2015} & Maret & 25000 & \multirow{3}{*}{176300} \\
\hline & Febuari & 49900 & \\
\hline & Januari & 101400 & \\
\hline \multirow{10}{*}{2014} & Oktober & 24820 & \multirow{10}{*}{440680} \\
\hline & September & 51536 & \\
\hline & Agustus & 51997 & \\
\hline & Juli & 66750 & \\
\hline & Juni & 115000 & \\
\hline & Mei & 22400 & \\
\hline & April & 37000 & \\
\hline & Maret & 45676 & \\
\hline & Febuari & 316 & \\
\hline & Januari & 25185 & \\
\hline \multirow{10}{*}{2013} & Desember & 49875 & \multirow{10}{*}{314870} \\
\hline & November & 8325 & \\
\hline & Oktober & 50600 & \\
\hline & September & 16000 & \\
\hline & Juni & 49900 & \\
\hline & Mei & 25500 & \\
\hline & April & 41000 & \\
\hline & Maret & 24970 & \\
\hline & Febuari & 20500 & \\
\hline & Januari & 28200 & \\
\hline
\end{tabular}

\section{Lampiran 5}

\begin{tabular}{|c|c|c|c|c|}
\hline Petani kelapa & Batok kelapa & & & \\
\hline Petani kelapa & Batok kelapa & $\begin{array}{l}\text { Kelompok } \\
\text { tani }\end{array}$ & Arang & $\begin{array}{l}\text { Unit usaha } \\
\text { briket } \\
\text { tempurung }\end{array}$ \\
\hline Petani kelapa & Batok kelapa & & & arang \\
\hline
\end{tabular}




\section{Lampiran 6. Tata Letak Bangunan Unit Usaha Tunas Muda}

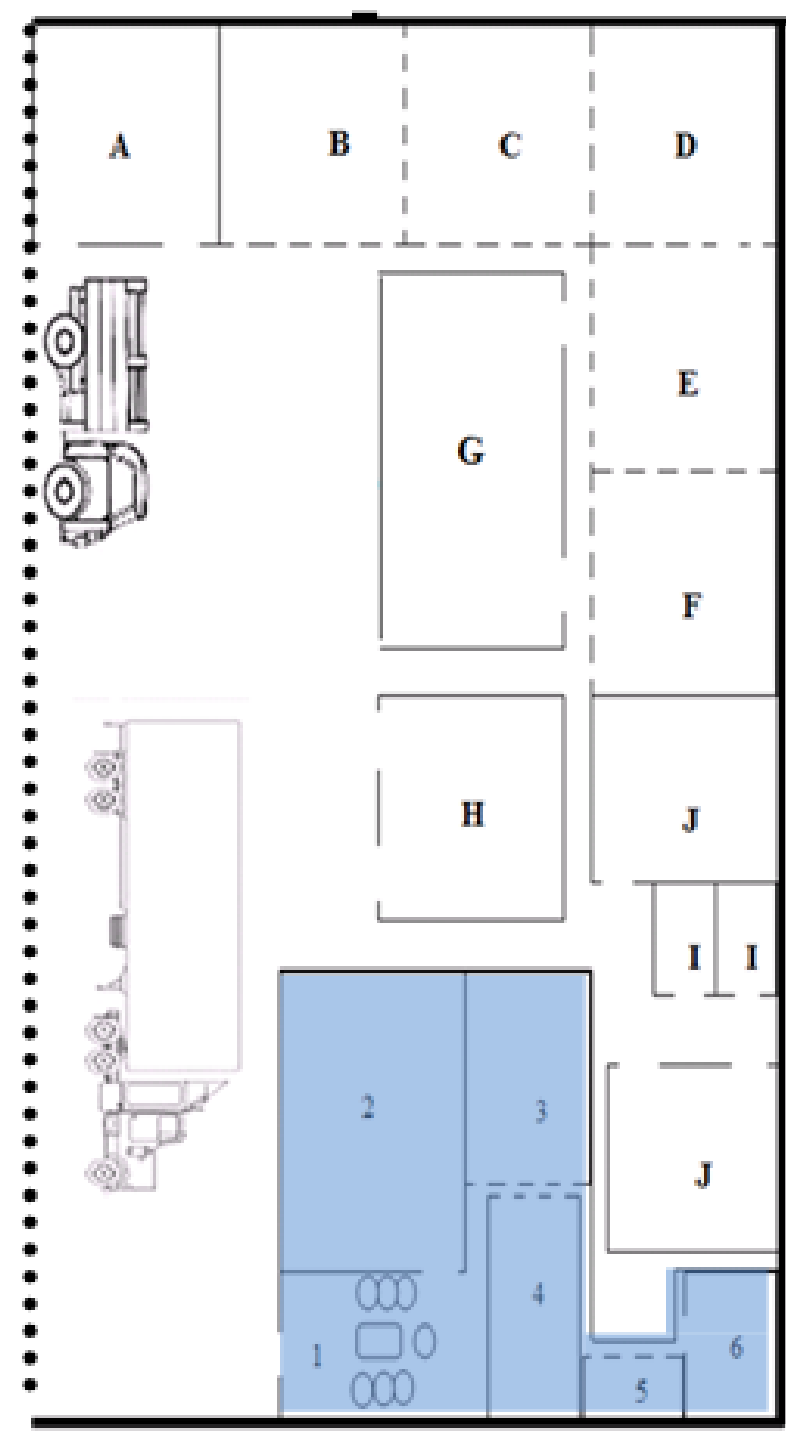

Keterangan :

1 = Ruang tamu

2 = Ruang pengelola usaha

3 = Ruang pengarsipan

4 = mushola kantor

5 = Ruang pengarsipan

6 = Toilet

A $=$ Gudang bahan baku

$\mathrm{B}=$ Area penggilingan arang

$\mathrm{C}=$ Area pengayalsan

$\mathrm{D}=$ Area pencampuran adonan briket

$\mathrm{E}$ = Area pencetakan

$\mathrm{F}=$ Area pengemasan

$\mathrm{G}=$ Ruangan oven

$\mathrm{H}=$ Gudang produl $\mathrm{jadi}$

I $=$ Toilet

\section{$20,5 \mathrm{~m}$ \\ $---\quad=$ Tanpa

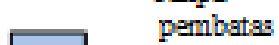 \\ $=$ Area kantor}

$\ldots \ldots \ldots$ = Gerbang

$13 \mathrm{~m}$ 


\section{Lampiran 7 Bagan Struktur Organisasi Unit Usaha Tunas Muda}

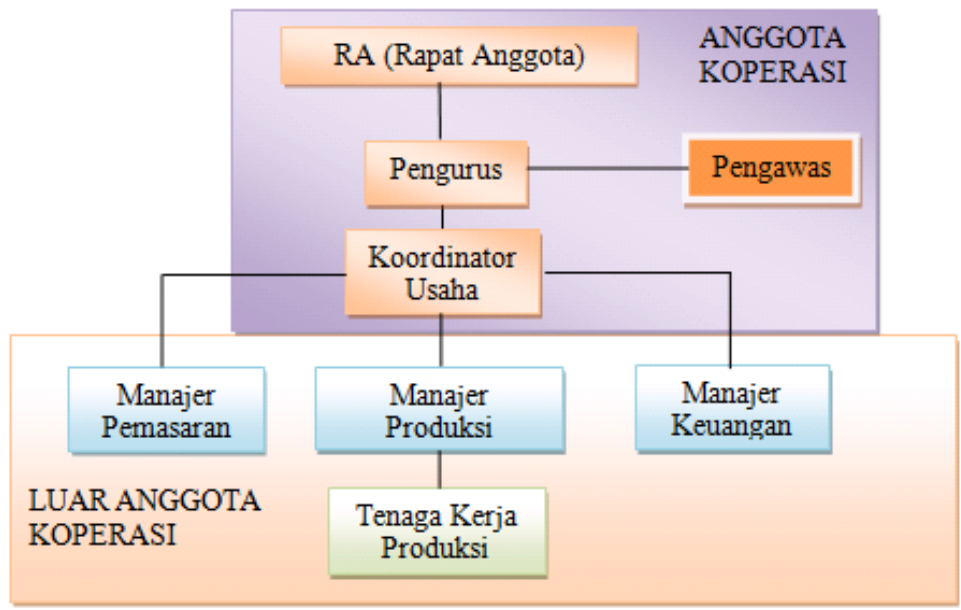

Lampiran 8. Diagram Hubungan Antar Petani, Industri, Wirakop, Koperasi, dan Investor

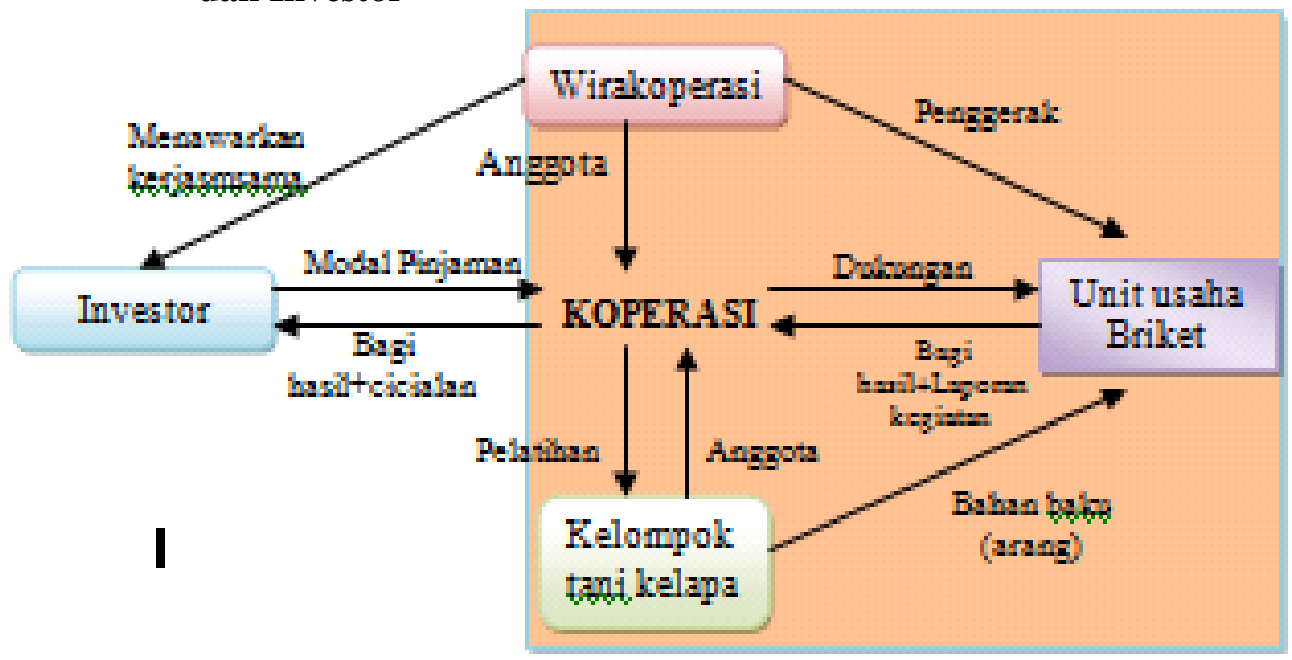

Lampiran 9. Rencana Biaya Investasi Unit Usaha Tunas Muda Proyeksi 10 Tahun

Biaya alat produksi Total biaya investasi

Biaya alat dan furnitur perkantoran

Biaya bangunan dan infrastruktur

Komponen biaya perijinan

Total
Biaya (Rp000)

275860

36985

257562

10300

580707 


\section{Lampiran 10. Rencana Biaya Variabel Secara Keseluruhan Unit Usaha Tunas Muda}

\begin{tabular}{|c|c|c|c|c|c|c|c|c|c|}
\hline \multirow[b]{2}{*}{ Komponen biaya } & \multirow[b]{2}{*}{ Satuan } & \multicolumn{2}{|c|}{ Jumlah } & \multicolumn{6}{|c|}{ Biaya (Rp 000) } \\
\hline & & $\begin{array}{c}\text { Bulan } \\
\text { tahun } \\
\text { perta- } \\
\text { ma }\end{array}$ & $\begin{array}{c}\text { Bulan } \\
\text { tahun } \\
\text { selanjut } \\
\text {-nya }\end{array}$ & $\begin{array}{c}\text { Per } \\
\text { satuan }\end{array}$ & $\begin{array}{c}\text { Bulan } \\
\text { pertama } \\
\text { pada } \\
\text { tahun } \\
\text { pertama }\end{array}$ & $\begin{array}{c}\text { Bulan } \\
\text { selanjut- } \\
\text { nya pada } \\
\text { tahun } \\
\text { pertama }\end{array}$ & $\begin{array}{c}\text { Bulan } \\
\text { Tahun } \\
\text { Selanjut - } \\
\text { nya }\end{array}$ & $\begin{array}{c}\text { Tahun } \\
\text { pertama }(6 \\
\text { bulan } \\
\text { produksi) }\end{array}$ & $\begin{array}{l}\text { Tahun } \\
\text { selanjut } \\
\text { nya }\end{array}$ \\
\hline Biaya tenaga supir & Kepergian & 8 & 8 & 100 & 800 & 800 & 800 & 4800 & 9600 \\
\hline Tenaga angkut & Pengangkutan & 10 & 10 & 300 & 3000 & 3000 & 3000 & 18000 & 36000 \\
\hline Biaya pengemasan & & & & & 49644 & 70920 & 78800 & 404244 & 945600 \\
\hline $\begin{array}{l}\text { Biaya bahan baku } \\
\text { produksi }\end{array}$ & & & & & 218349 & 218349 & 218349 & 1310096 & 2620191 \\
\hline $\begin{array}{l}\text { Biaya transportasi } \\
\text { pengadaan bahan } \\
\text { baku }\end{array}$ & & 10 & 10 & 100 & 800 & 800 & 800 & 4800 & 9600 \\
\hline $\begin{array}{l}\text { Biaya Pemasaran } \\
\text { dan pengiriman } \\
\text { barang }\end{array}$ & & & & & 4150 & 8300 & 8300 & 45650 & 99600 \\
\hline Total & & & & & 276743.3 & 302169 & 310049 & 1787590 & 3720591 \\
\hline
\end{tabular}

Lampiran 11. Rencana biaya tetap secara keseluruhan unit usaha Tunas Muda

\begin{tabular}{lrrr}
\hline \multirow{2}{*}{ Komponen Biaya } & \multicolumn{3}{c}{ Jumlah Biaya (Rp 000) } \\
\cline { 2 - 4 } & Per bulan & Tahun pertama & Tahun selanjutnya \\
\hline Tenaga kerja tetap & 43290 & 259740 & 519480 \\
Biaya utility & 1460 & 8760 & 17520 \\
Administrasi perkantoran & 235 & 1410 & 2820 \\
Biaya jaminan mutu & 7700 & 46200 & 92400 \\
perlengkapan kerja & 350 & 2100 & 4200 \\
Total & 53035 & 318210 & 636420 \\
\hline
\end{tabular}

\section{Lampiran 12. Rencana Jadwal Produksi Unit Usaha Tunas Muda}

\begin{tabular}{|c|c|c|c|c|c|c|c|}
\hline Hari kerja & Penggilingan & Pengayakan & Pengadukan & Pencetakan & Pengeringan & Pengemasan & Output (Ton) \\
\hline 1 & & & & & & & \\
\hline $\begin{array}{l}2 \\
3\end{array}$ & & & & & & & \\
\hline 4 & & & & & & & \\
\hline 5 & & & & & & & \\
\hline 6 & & & & & & & \\
\hline$?$ & & & & & & & \\
\hline 9 & & & & & & & $\frac{1}{1}$ \\
\hline 10 & & & & & & & $\frac{2}{1}$ \\
\hline 11 & & & & & & & 1. \\
\hline 12 & & & & & & & 1. \\
\hline 13 & & & & & & & 1. \\
\hline 14 & & & & & & & 1. \\
\hline 15 & & & & & & & \\
\hline 16 & & & & & & & 1. \\
\hline 17 & & & & & & & 1. \\
\hline 18 & & & & & & & \\
\hline 19 & & & & & & & \\
\hline & & & tal output di b & 1 pertama & & & 252 \\
\hline
\end{tabular}

Pada bulan di tahun pertama selanjumya sudah dapatstabilmenjadi 36 ton per bulan

Sedangkan pada bulan di tahun berikutnya menjadi 2 ton per hari sehingga per bulan menghasilkan 40 ton 


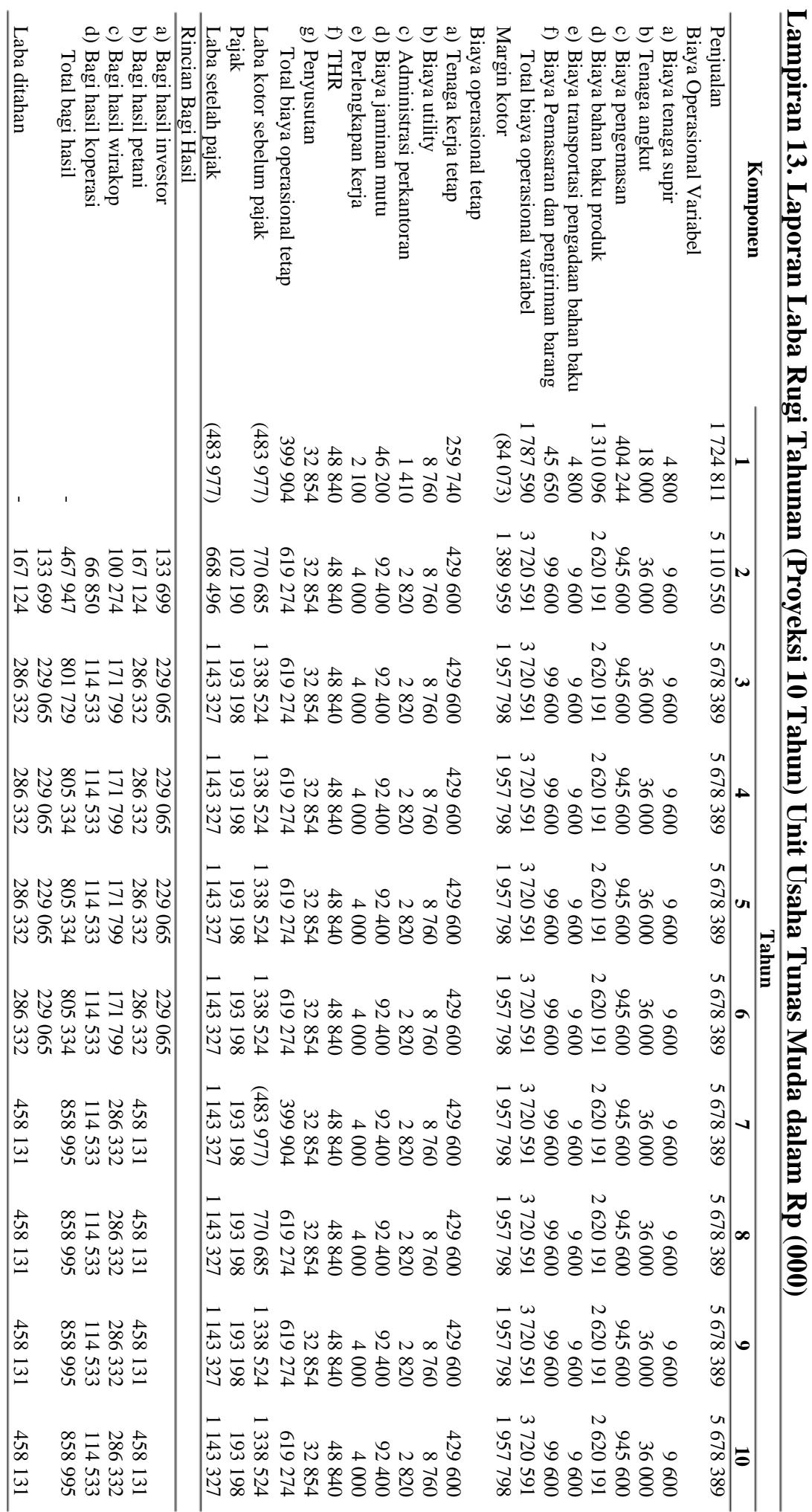




\section{Lampiran 14. Laporan Arus Kas Bulanan (Proyeksi 1 Tahun Pertama) Unit} Usaha Tunas Tunas Kelapa dalam (Rp 000)

\begin{tabular}{|c|c|c|c|c|c|c|c|}
\hline \multirow{2}{*}{ Rincian komponen } & \multicolumn{7}{|c|}{ Bulan ke } \\
\hline & 1 sampai 6 & 7 & 8 & 9 & 10 & 11 & 12 \\
\hline \multicolumn{8}{|l|}{ Inflow } \\
\hline 1. Penjualan & & 149058 & 255528 & 298115 & 319409 & 340703 & 340703 \\
\hline 2. Pinjaman dari investor & 580707 & 129778 & & & & & \\
\hline Total intflow & 580707 & 278836 & 255528 & 298115 & 319409 & 340703 & 340703 \\
\hline \multicolumn{8}{|l|}{ Outflow } \\
\hline 1. Biaya investasi & 580707 & & & & & & \\
\hline Total biaya investasi & 580707 & & & & & & \\
\hline \multicolumn{8}{|l|}{ 2. Biaya operasional } \\
\hline a. Biaya tetap & & 53035 & 53035 & 53035 & 53035 & 53035 & 53035 \\
\hline b. Biaya variabel & & 276743 & 302169 & 302169 & 302169 & 302169 & 302169 \\
\hline Total biaya opersional & & 329778 & 355204 & 355204 & 355204 & 355204 & 355204 \\
\hline \multicolumn{8}{|l|}{ 3. Biaya non operasional } \\
\hline a. Tunjangan hari raya (THR) & & & 48840 & & & & \\
\hline b. Kewajiban kredit pinjaman & & & & & & & \\
\hline $\begin{array}{l}\text { c. Pajak } \\
\text { Total biaya non operasional }\end{array}$ & & & 48840 & & & & \\
\hline Total outflow & 580707 & 329778 & 361904 & 355204 & 355204 & 355204 & 355204 \\
\hline Net benefit & - & (50 942) & (106 377) & (57 089) & (35 795) & $(14501)$ & $(14$ 501) \\
\hline Total nett benefit tahun pertama & & & & & & & (279 205) \\
\hline
\end{tabular}




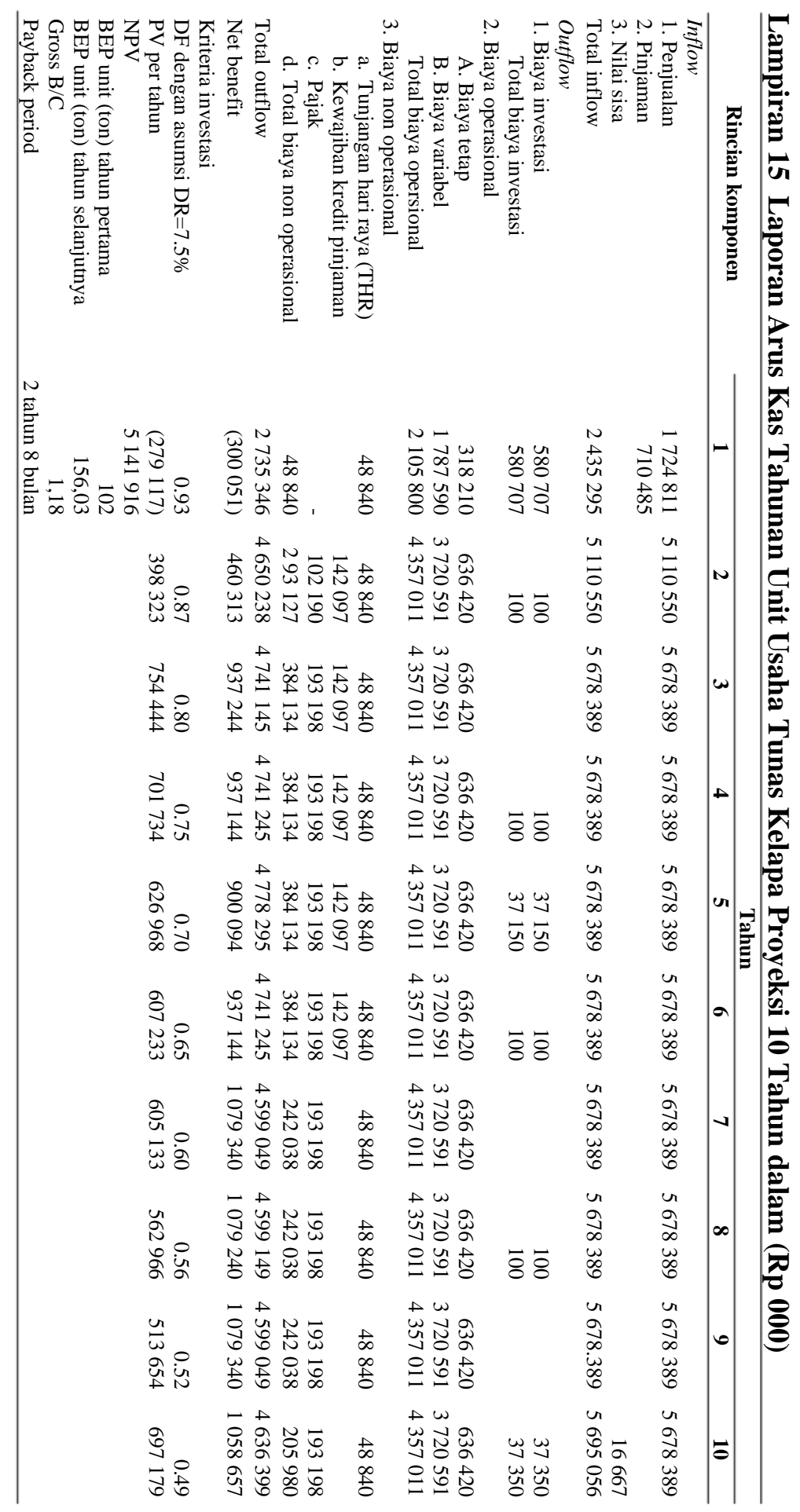


Fitria Na'imatu Sa’diyah, dan Lukman M Baga 